\title{
PONDOK PESANTREN DALAM PENGEMBANGAN PENDIDIKAN KEISLAMAN
}

\author{
Oleh. \\ Sumarto \\ STAI Ma’arif Jambi \\ sumarto.manajemeno@gmail.com
}

\begin{abstract}
Historically, Islamic boarding schools were Islamic educational institutions developed by Indonesian people. Because actually pesantren is a cultural product of Indonesian people who are fully aware of the importance of education for indigenous people who grow naturally. Regardless of where the tradition and system is adopted, it will not affect unique patterns and have taken root and lived in the community. The pattern of life in pesantren is formed naturally through the process of planting values and developing the process of influencing influence with society. Islamic boarding schools always experience dynamics that never stop, in line with the social changes that occur.

In the pesantren management system, the existence of a vision and mission occupies an important position. The vision must be formulated earlier and then set forth in the mission, namely programs and activities to realize the vision, and furthermore is to compile an action program in a mature and flexible plan to be implemented in a certain period of time in stages. The vision and mission of Islamic education which is the hope, ideals, and goals of Islamic education, are basically built from Islamic values and the results of analysis of the existence of Islamic education.

Islamic boarding schools should be the center of Islamic education development, because; Islamic Boarding School is a center of religious education, which combines general and religious education, becomes a fortress for scientific balancers which are increasingly rapid by the influence of globalization, the development of science and knowledge is unstoppable, so Islamic boarding schools present as a fortress to provide boundaries that are in accordance with Islamization. This paper explains how Islamic boarding schools should be in developing Islamic education, preserving and preserving Islamic scholarship as a practice and practice.
\end{abstract}

Keyword: Pondok Pesantren, Islamic Education

\begin{abstract}
Abstrak
Secara historis, pesantren merupakan lembaga pendidikan Islam yang dikembangkan oleh masyarakat Indonesia. Karena sebenarnya pesantren merupakan produk budaya masyarakat Indonesia yang sadar sepenuhnya akan pentingnya arti sebuah pendidikan bagi orang pribumi yang tumbuh secara natural. Terlepas dari mana tradisi dan sistem tersebut diadopsi, tidak akan mempengaruhi pola yang unik (khas) dan telah mengakar serta hidup dan berkembang di tengah masyarakat.Pola kehidupan di pesantren terbentuk secara
\end{abstract}


alamiah melalui proses penanaman nilai dan berkembangnya proses pengaruh mempengaruhi dengan masyarakat. Pesantren selalu mengalami dinamika yang tidak pernah berhenti, sejalan perubahan sosial yang terjadi.

Dalam sistem pengelolaan pesantren, keberadaan visi dan misi menempati posisi penting. Visi harus dirumuskan lebih awal yang kemudian dituangkan dalam misi, yaitu program-program dan kegiatan-kegiatan untuk mewujudkan visi tersebut, dan lebih jauhnya adalah menyusun program aksi di dalam sebuah rencana yang matang dan fleksibel untuk dapat dilaksanakan dalam jangka waktu tertentu secara bertahap. Visi dan misi pendidikan Islam yang merupakan harapan, cita-cita, dan tujuan pendidikan Islam, pada dasarnya dibangun dari nilai-nilai Islam dan hasil analisa terhadap keberadaan pendidikan Islam.

Sudah seharusnya Pondok Pesantren sebagai pusat pengembangan pendidikan ke-Islaman, dikarenakan; Pondok Pesantren adalah pusat pendidikan keagamaan, yang memadukan pendidkan umum dan keagamaan, menjadi benteng untuk penyeimbang keilmuan yang semakin hari semakin pesat oleh pengaruh globalisasi, perkembangan ilmu dan pengetahuan tidak terbendung lagi, sehingga Pondok pesantren hadir sebagai benteng untuk memberikan batasan-batasan yang sesuai dengan ke-Islaman. Tulisan ini menjelaskan tentang bagaimana seharusnya pondok pesantren dalam mengembangkan pendidikan ke-Islaman, menjaga dan melestarikan keilmuan ke-Islaman sebagai ajaran dan amalan.

\section{Kata Kunci: Pondok Pesantren, Pendidikan Ke-Islaman}

\section{A. PENDAhULUAN}

Di Indonesia, istilah pesantren dengan sebutan pondok pesantren. Lain halnya dengan pesantren, pondok berasal dari bahasa Arab, yang berarti hotel, asrama, rumah, dan tempat tinggal sederhana. Menurut Dofier yang dikutip oleh Kasful Anwar Us, kata pesantren berasal dari kata santri, dengan awalan pe di depan dan akhiran an berarti tempat tinggal para santri. ${ }^{1}$ Berangkat dari pengertian di atas, secara kultural menunjukkan bahwa pesantren lahir dari budaya Indonesia.

Pengelolaan pesantren harus secara luas bersadarkan unsur-unsur penting antara lain Misi pesantren yang sesuai dengan filosofis pendidikan Islam, struktur organisasi fungsional

${ }^{1}$ Kasful Anwar, Kepemimpinan Pondok Pesantren, Disertasi: UPI, hal. 51. pesantren, kemitraan dan pelayanan yang baik, perencanaan dan pengembangan pesantren, pengelolaan dan supervisi SDM, dinamika dalam menjalankan strategi pembelajaran, penguatan kurikulum praktis, pengelolaan Sumber Daya Belajar secara efisien, pengelolaan dan pemeliharaan fasilitas pesantren. $^{2}$

$$
\text { Pengelolaan pesantren }
$$
merupakan pengelolaan pendidikan untuk merencanakan program pendidikan dan membuat keputusan yang berupa tindakan-tindakan nyata yang dilakukan secara komprehensif untuk meng-cover seluruh kebutuhankebutuhan pesantren, visi, misi, dan

Haedari, Amin dan Ishom El-
Saha, Peningkatan Mutu Terpadu
Pesantren dan Madrasah Diniyah.
(Jakarta: Diva Pustaka, 2008), hal. 56.


tujuan pendidikan pesantren. Di mana di dalamnya ada regulasi, aturan, dan kesepakatan yang tidak boleh berseberangan dengan regulasi, aturan, yang lebih tinggi daripada aturan pesantren. ${ }^{3}$

Khusus dalam bidang pendidikan, misalnya, pesantren dapat dikatakan kalah bersaing dalam menawarkan suatu model pendidikan kompetitif yang mampu melahirkan santri yang memiliki kompetensi dalam penguasaan ilmu sekaligus skill sehingga dapat menjadi bekal terjun ke dalam kehidupan sosial yang terus mengalami percepatan perubahan akibat modernisasi yang ditopang kecanggihan sains dan teknologi.

Sistem pendidikan di pesantren menggunakan sistem pendidikan tradisional, dengan ciri adanya kebebasan penuh dalam proses pembelajarannya, terjadinya hubungan interaktif antara kyai dan santri. Peserta didik (para santri) dalam menempuh pendidikan di pesantren tidak berorientasi semata mencari ijazah dan gelar, sebagaimana sistem pendidikan di sekolah formal.

Kultur pendidikan diarahkan untuk membangun dan membekali para santri agar hidup sederhana, memiliki idealisme. Dalam sejarahnya, alumni pesantren umumnya tidak bercita-cita untuk menjadi atau menguasai kedudukan (jabatan) di pemerintahan, karena itu mereka juga sulit untuk bisa dikuasai oleh pemerintah.

${ }^{3}$ Diding Nurdin,Pengelolaan Pendidikan dari Teori Menuju Implementasi, (Jakarta: Raja Grafindo Persada, 2015), hal. 45.

Terkait dengan manajemen pesantren yang merupakan sarana penggunaan sumberdaya yang efektif untuk mencapai sasaran, maka perlu adanya stretegi atau siasat seperti ditegas oleh Mujamil Qomar bahwa manajemen penuh siasat yang diarahkan untuk mencapai sebuah tujuan. Sebagai seni, manajemen lebih menitikberatkan pada peranan manusia sebagai pelaku manajemen dengan menggunakan pendekatan scientific, tetapi juga professional. Merupakan Lembaga Pendidikan Islam yang paling variatif adalah Pesantren, mengingat adanya kebebasan dari kiai pendirinya untuk mewarnai pesantrennya itu penekannya pada kajian tertentu.

Misalnya, ada pesantren ilmu " alat", pesantren fiqih, Pesantren Al Qur'an, Pesantren hadits, atau pesantren tasawuf. Masing-Masing didasarkan pada keahlian kiainnya. Ditinjau dari segiterbukaan terhadap perubahan-perubahan yang terjadi dari luar, pesantren dapat dibagi dua: Pertama, Pesantren salafi dan kedua pesantren Pesantren khalafi. Pesantern salafi bersifat kenservatif sedangan khalafi bersifat adaptif. Adaptasi dilakukukan terhadap perubahan dan pengembangan pendidikan yang merupakan akibat dari tuntutan perkembangan sains dan teknologi.

Pesantren salafi r pada
umumnya para santri kuat dalam
tela'ah kitab-kitab warisan ulama'
klasik. Mereka menguasai teori Bahasa
Arab secara baik, namun kurang
menekankan aspek praktis dari


pemanfa'atan bahasa sebagai alat komunikasi verbal. Sebaliknya, sistem yang kedua khalafi pada umumnya, kurang dalam penguasaan kitab klasik, namun mereka telah membiasakan Bahasa Arab dan Bahasa Inggris sebagai bahasa pengantar keseharian.

Perbedaan

pesantren

tradisional dengan pesantren modern dapat diidenfifikasi dari perpespektif manajerialnnya. Pesantren modern telah dikelola secara rapi dan sistematis dengan mengikuti kaidah-kaidah manajerial yang umum. Sementara itu, pesantren tradisional berjalan secara alami tanpa berupaya mengelola secara efektif. $^{4}$

Masa Depan pesantren sangat ditentukan oleh faktor manajerial. Pesantren kecil akan berkembang secara signifikan manakala dikelola secara profesioanal. Dengan pengelolaan yang sama pesantren yang mudah besar akan bertambah besar. Sebaliknya pesantren yang maju akan mengalami kemunduran manakala manajemennya tidak terurus dengan baik. Jika pesantren mengabaikan manajemen, pesantren kecil akan gulung tikar dalam mengahadapi multideimensi.

Pola-Pola

kepemimpinan kiai di pesantren yang selama ini kurang kondusif menghadapi tantangan-tantangan moderenisasi bahkan perlu diubah menjadi pola-pola kepemimpinan yang lebih responsif terhadap tuntutan kemajuan zaman. Pola tersebut haruslah mengarah pada kegiatan yang

4 Mujamil Qomar, Manajemen Lembaga Pendidikan Islam, (Jakarta: Erlangga, 2007), hal. 11. melibatkan lebih banyak orang lain lagi dalam jajaran kepemimpinan, untuk bersama-sama menjalankan roda organisasi pesantren menuju kondisi yang maju dan mapan, baik dari sisi kelembagaan, sistem pendidikan, proses pembelajaran, maupun kualitas santri.

$\begin{array}{ccc}\text { Kasus } & \text { yang ada pada } \\ \text { beberapa } & \text { pesantren } & \text { telah }\end{array}$
membuktikan bahwa peran serta kiai dalam mengelola, mengembangkan dan menata pesantren sehingga dapat muncul sebagai sebuah lembaga yang dapat dijadikan pendidikan alternatif memiliki peranan yang sangat besar, sebab tidak jarang pesantren akan tutup dikarenakan oleh beberapa hal yakni: pertama kharismatik kiai di pesantren tersebut telah luntur bersama meninggalnya kiai utama sebagai pendirinya, Kedua tidak adanya pengganti yang dapat meneruskan estapet kepemimpinanya, Ketiga kesibukan kiai yang dapat mengabaikan proses belajar mengajar, Keempat kurang seimbangnya tuntutan kebutuhan belajar santri dengan pelayanan yang diberikan oleh pesantren tersebut.

Pendidikan di pesantren tidak dapat dilepaskan dengan masalah pengelolaan dan pengembangan. Manajemen merupakan terjemahan secara langsung dari kata management yang berarti pengelolaan, ketatalaksanaan, atau tata pimpinan. Management berakar dari kata kerja to manage yang berarti mengurus, mengatur, atau mengelola. ${ }^{5}$

\footnotetext{
${ }^{5}$ Ramayulis, Ilmu Pendidikan Islam, (Jakarta: Kalam Mulia, 2007), hal. 259.
} 
Sistem pengelolaan dalam pendidikan Islam merupakan proses yang koordinatif, sistematis dan integratif. Proses itu dimulai dengan dari perencanaan, pengorganisasian, penggerakan, sampai pada pengawasan. Proses ini selalu didasari oleh nilai-nilai Islam. Oleh karena itu sistem tersebut sekaligus mempunyai nilai materil dan spritual.

Sedangkan pengembangan adalah suatu proses mendapatkan pengalaman, keahlian dan sikap untuk menjadi sesuatu atau meraih sukses sebagai pemimpin dalam organisasi mereka. Oleh karena itu, kegiatan pengembangan ditujukan untuk membantu seseorang untuk dapat menangani persoalannya di masa mendatang, dengan memperhatikan tugas dan kewajiban yang dihadapi sekarang. ${ }^{6}$

\section{B. PEMBAHASAN}

\section{Pondok Pesantren}

Pondok

Pesantrenmerupakanorganisasi yang susunannya berdasarkan atas fungsifungsi yang ada dalam organisasipesantren tersebut. Dalam organisasi ini seorang tenaga pengajar tidak hanya bertanggung jawab kepada satu atasan saja. Pada organisasi ini pemimpin berhak memerintahkan semua para tenaga pengajar/para stafnya, selama masih dalam hubungan pekerjaan. Sehingga seorang pekerja dapat saja diperintah oleh lebih dari satu pimpinan sesuai dengan

${ }^{6}$ Veithzal Rivai, dkk, Education Management Ed. 1, (Jakarta: Rajawali, 2010), hal. 2. keahliannya. ${ }^{7}$ Dalam organisasi terdapat bermacam-macam struktur organisasi.

Kemitraan diarahkan untuk mencapai tujuan sebagaimana yang diinginkan individu, kelompok, lembaga atau organisasi untuk menghasilkan suatu keluaran yang bermakna dan berkelanjutan. Dalam kemitraan terjadi relasi antarorganisasi dan dengan relasi tersebut akan tercipta kerja sama. ${ }^{8}$

Pelayanan yang baik dapat dipahami sebagai suatu usaha oleh seorang/kelompok orang, atau institusi tertentu khususnya pesantren untuk memberikan kemudahan dan bantuan kepada masyarakat dalam rangka mencapai tujuan tertentu. Hanya saja, dalam rangka melakukan optimalisasi pelayanan publik yang dilakukan oleh birokrasi pemerintahan bukanlah tugas yang mudah mengingat usaha tersebut menyangkut berbagai aspek yang telah membudaya dalam lingkaran birokrasi pemerintahan.

Rencana strategis ini dibangun berdasarkan visi pondok pesantren yang mendorong cita-cita dan komitmen bersama tentang kondisi ideal masa depan yang ingin dicapai dengan mempertimbangkan potensi yang dimiliki, permasalahan yang dihadapi dan berbagai kecenderungan (perubahan lingkungan) yang sedang dan akan berlangsung. Berdasarkan visi

\footnotetext{
${ }^{7}$ A Azra, D Afrianti, The Journal of Islamic Boarding School Pesantren and Madrasah: Muslim School and National Ideals in Indonesia, RW Hefiner and Politics of Modern Muslim, 2008.

${ }^{8}$ Umar Sidiq, Pengembangan Standarisasi Pondok Pesantren, Jurnal Pendidikan Nadwa, Vol. 7, Nomor 1 April 2013.
} 
selanjutnya dirumuskan berbagai tujuan dan sasaran yang akan dicapai lima tahun ke depan. ${ }^{9}$

Berdasarkan tujuan dan sasaran tersebut, selanjutnya dirumuskan rumusan untuk mencapainya.Rumusan tersebut meliputi strategi dan program pengembangan yang perlu ditempuh, beserta indikator-indikator keberhasilannya.

Pesantren kecil akan berkembang secara signifikan manakala dikelola secara profesional. Dengan pengelolaan yang sama, pesantren yang sudah besar akan bertambah besar lagi, sebaliknya, pesantren yang telah maju akan mengalami kemunduran manakala pengelolaannya tidak terurus dengan baik. Sementara itu, jika mengabaikan pengelolaan, pesantren yang kecil akan gulung tikar dalam menghadapi tantangan multidimensi.

Suasana pembelajaran harus ditranformasikan ke dalam suasana pembelajaran yang kondusif dan memfasilitasi penguatan daya kritis para santri melalui berbagai kondisi dan pengembangan wawasan yang diperkuat oleh pendekatan-pendekatan metodologis.

Pesantren perlu meninjau kembali penekanan kajian yang selama ini lebih terkosentrasi pada ilmu "alat" Nahwu, Shorof, dan lain-lain) dan ilmu Fikih. Kedua disiplin ilmu yang menjadi konsentrasi kajian di pesantren ini sama-sama berdimensi hukum. Ilmu

9 Soekidjo Notoatamodjo, Pengembangan Sumber Daya Manusia, (Jakarta: PT. Rineka Cipta, 2008), hal. 28. alat berisi hukum atau peraturan tata bahasa, sedang ilmu Fikih merupakan ilmu hukum Islam. Kesamaan dimensi dari ilmu alat dan ilmu Fikih itulah yang menyebabkan pola-pola pemahaman di pesantren terasa kaku, padahal ilmu Fikih sebenarnya harus senantiasa mengawal perkembangan.

Untuk itu, pesantren di masa mendatang tidak hanya berorientasi pada pemahaman teks Fikih secara ekslusif semata, tetapi lebih dari itu diarahkan pada paradigma Fikih holistik, yakni pemikiran baru yang mencakup seluruh aspek kehidupan yang termasuk dalam tataran berbangsa dan bernegara secara praktis.

Sumber belajar yang dirancang atau secara sengaja dibuat atau dipergunakan untuk membantu belajar mengajar, Sumber belajar semacam ini sering disebut bahan pembelajaran. Misalnya buku pelajaran, modul, brosur, ensiklopedi, program audio, program slide suara, film, video, slides, film strips, transparansi. Semua perangkat keras ini memang secara sengaja dirancang guna kepentingan pengajaran. ${ }^{10}$

Sumber belajar yang
dimanfaatkan kemudahan seseorang dalam belajar berupa segala macam sumber belajar yang ada disekitar lingkungan pesantren, sudah tersedia dan tinggal dimanfaatkan. Sumber belajar tersebut tidak dirancang untuk kepentingan

\footnotetext{
10 Udin Syaefudin Sa'ud dan Abin Syamsuddin, Perencanaan Pendidikan Suatu Pendekatan Komprehensif, (Bandung: Pt Remaja Rosdakarya, 2008), hal. 39.
} 
tujuan suatu kegiatan pengajaran, namun dapat ditemukan, dipilih dan dimanfaatkan untuk keperluan pembelajaran. Misalnya taman, pasar, toko, museum, kebun binatang, waduk, sawah, terminal, surat kabar, siaran televisi, film, tokoh masyarakat, pejabat pemerintah, tenaga ahli, pemuka agama, olahragawan, dan sebagainya yang ada di lingkungan sekitar yang dapat dimanfaatkan untuk keperluan belajar.

\section{Konsep}

pengembangan

pengelolaan pondok pesantren harus lebih akomodatif terhadap perubahan yang serba cepat dalam era global saat ini. Oleh karena itu idealisme"lillahi ta'ala" harus dilapisi dengan profesionalisme yang memadai, sehingga dapat menghasilkan kombinasi yang ideal dan utuh yaitu idealism-profesionalisme. Dengan kombinasi konsep manajemen yang ideal tersebut diharapkan akan tetap dapat mempertahankan eksistensi pondok pesantren di satu sisi, serta dapat menigkatkan daya kompetitif pesantren dalam era global di sisi lainya. Kombinasi tersebut dapat menghasilkan konsep manajemen pondok pesantren dengan karakteristik baru yang ideal. Selain itu juga dapat disebut sebagai Manajemen Berbasis Pondok Pesantren (MBPP). Dengan MPBB baru tersebut diharapkan akan dapat menghasilkan karakteristik pondok pesantren yang efektif.

$$
\text { Karakteristik MBPP baru }
$$

tersebut dapat dianalisis dengan pendekatan sistem yaitu dari segi inputproses-output. Hal itu didasari atas pemikiran bahwa pondok pesantren merupakan suatu sistem sehingga menguraikan karakteristik MBPP juga didasarkan pada proses output yang dapat menunjang perkembangan pondok pesantren secara keseluruhan. Dimana karakteristik tersebut ditandai dengan adanya pondok pesantren yang didasarkan pada input maupun ouput yang ada.

Sistem evaluasi dan pertanggungjawaban merupakan kegiatan yang terusmenerus dan berkelanjutan untuk mengetahui kualitas dan kuantitas perubahan. Evaluasi merupakan subsistem yang sangat penting dan sangat dibutuhkan dalam setiap sistem pendidikan, karena evaluasi dapat mencerminkan seberapa jauh perkembangan atau kemajuan hasil pendidikan. Dengan evaluasi, maka maju dan mundurnya kualitas pendidikan dapat diketahui, dan dengan evaluasi pula, kita dapat mengetahui titik kelemahan serta mudah mencari jalan keluar untuk berubah menjadi lebih baik ke depan. ${ }^{11}$

Tanpa evaluasi dan pertanggungjawaban, kita tidak akan bisa mengetahui seberapa jauh keberhasilan santri, dan tanpa evaluasi pula kita tidak akan ada perubahan menjadi lebih baik, maka dari itu jadi secara umum evaluasi adalah suatu proses sistemik untuk mengetahui tingkat keberhasilan suatu program.

\section{Pengembangan Pendidikan Ke-Islaman \\ Pada awalnya adalah hanya} pengajaran yang simpel tidak ada

Zainuddin Ali, Pendidikan Agama Islam, (Jakarta: Bumi Aksara, 2012), hal. 23. 
kurikulum tidak seperti sekarang ini. Sebenarnya pembelajaran yang diberikan dalam pondok pesantren sudah menggunakan kurikulum tertentu yang lama yaitu sistem pengajaran tuntas kitab, dalam hal ini kyai bebas untuk membacakan kitabnya. ${ }^{12}$

Materi pelajaaran umum menjadi begitu tampak seiring dengan dianutnya triple curriculum yakni kurikulum pondok, Kementerian Pendidikan Nasional dan Kementerian Agama. Tekanan pada Bahasa Arab dengan mudah dpat dipahami latar belakangnya. Bahasa Arab adalah sebagai alat dalam memahami dan mendalami ajaran Islam terutama yang teruraikan dalam alqur'an dan alhadits, dan kitab-kitab Islam klasik. ${ }^{13}$

Alat memang harus dilengkapi dulu sebelum mencapai sasaran dalam upaya pencapaian tujuan. Jika ilmu alat yang meliputi berbagai cabang itu telah dikuasai santri, maka harapan kyai terhadap penguasaan santri terhadap berbagai bidang ilmu lainnya akan segera menjadi kenyataan.

Sistem pengajaran dapat diartikan sebagai cara yang dipergunakan untuk menyampaikan tujuan. Pondok pesantren secara agak seragam menerapkan sistem pengajaran yang sering kita kenal yaitu: sorogan, bandungan, hafalan dan masih banyak lainnya. Akan tetapi konsep keilmuan

${ }^{12}$ Mujamil Qomar, Manajemen Pendidikan Islam, (Malang: Erlangga, 2008), hal. 62.

${ }^{13}$ Badarus Syamsi, Akulturasi Pesantren Jawa di Jambi, Kontektualita, Vol. 28, No. 1, (Institut Agama Islam Negeri (IAIN) Sulthan Thaha Saifuddin Jambi, 2013), hal. 53. lebih menekankan pada rasionalitas seperti yang menjadi dasar pendidikan modern.

Pondok pesantren sebagai lembaga non formal juga sebagai lembaga sosial keagamaan. Dan perjalanannya, pembiayaan dalam bidang pendidikan pesantren bisa didapat dari swadya pemerintah, yaitu Kemenag, Link Kemenag, Instansi Daerah maupun dari lainnya. Karena kepedulian pesantren ini dilandasi dengan keikutsertaan pemerintah dalam memajukan pondok pesantren dengan karakternya yang khas.

\section{Karakter Pondok Pesantren}

Menurut Dofier yang dikutif oleh Kasful Anwar Us, pesantren terdiri dari lima elemen, yaitu: kyai, santri, pondok, masjid, dan pengajaran kitab kuning. Kelima elemen tersebut merupakan ciri khusus yang dimiliki pesantren dan membedakan pendidikan pondok pesantren dengan lembaga pendidikan dalam bentuk lain. Sebagaimana yang akan peneliti uraikan berikut ini:

\section{a. Kyai}

Kyai atau pengasuh pondok pesantren merupakan elemen yang sangat esensial bagi suatu pesantren juga sekaligus sebagai penggagas dan pendiri dari pesantren yang bersangkutan. Maka, sangat wajar dalam pertumbuhannya, pesantren bergantung pada peran seorang kyai.

Seorang kyai disebut alim bila ia benar-benar dapat memahami, dan dapat mengamalkan dan memfatwakan kitab kuning. Keilmuan seorang kyai yang menjadi daya tarik tersendiri 
terhadap santri untuk memilih pesantren dan menjadikan seorang kyai lebih berwibawa baik di hadapan para santrinya sendiri maupun masyarakat.

\section{b. Masjid}

Elemen kedua yang juga tidak terpisahkan dari pesantren adalah masjid. Peran masjid sangat sentral sekali. Masjid sebagai pusat kegiatan ibadah dan belajar mengajar merupakan sentral sebuah pesantren karena di sinilah tahap awal bertumpu seluruh kegiatan di lingkungan pesantren, baik yang berkaitan dengan ibadah, shalat berjama'ah, zikir, wirid, do'a, i'tikaf, dan juga kegiatan belajar mengajar.

Seorang kyai yang ingin mengembangkan pesantren, pada umumnya yang pertama-tama menjadi prioritas adalah masjid. Masjid dianggap sebagai simbol yang tidak terpisahkan dari pesantren. Masjid tidak hanya sebagai tempat praktek ritual ibadah, tetapi juga tempat pegajaran kitab-kitab klasik dan aktifitas pesantren lainnya.

\section{c. Santri}

Santri merupakan unsur yang penting sekali dalam perkembangan sebuah pesantren, karena langkah pertama dalam tahap-tahap membangun pesantren adalah bahwa harus ada murid yang datang untuk belajar dari seorang alim, baru seorang alim itu bisa disebut kyai dan mulai membangun fasilitas yang lebih lengkap untuk pondoknya.

Santri biasanya terdiri dari dua kelompok, yaitu santri kalong dan santri mukim. Santri kalong merupakan bagian santri yang tidak menetap di pondok tetapi pulang ke rumah sesudah selesai mengikuti suatu pelajaran di pesantren. Santri kalong biasanya berasal dari daerah-daerah di sekitar pesantren. Makna santri mukim ialah putera atau puteri yang menetap dalam pondok pesantren biasanya berasal dari daerah jauh.

\section{d. Pondok}

Menurut Dofier yang dikutif oleh Kasful Anwar Us, istilah pondok berasal dari pengertian asrama-asrama para santri atau berasal dari kata Arab 'funduq', yang berarti hotel atau asrama, istilah pondok adalah penginapan santri dibangun karena kondisi jarak antara tempat tinggal santri dan Kyai cukup jauh, sehingga memaksa mereka untuk mewujudkan penginapan sekedarnya di sekitar masjid dan rumah Kyai.

Pesantren merupakan bapak dari pendidikan Islam di Indonesia, didirikan karena adanya tuntutan dan kebutuhan zaman. ${ }^{14}$ Ada beberapa tipe pondok pesantren misalnya, pondok pesantren salaf, khalaf, pondok pesantren terpadu, takhassus alQur'an, dan pesantren kilat. lembaga pondok pesantren mempunyai dasar ideologi keagamaan yang sama, namun kedudukan tiap pondok pesantren sangat bersifat personal dan sangat tergantung pada kualitas keilmuan yang dimiliki seorang kyai.

\section{e. Pengajaran Kitab Kuning}

Pengajaran kitab kuning berbahasa Arab dan tanpa harakat atau

${ }^{14}$ Amin Haedari, Peningkatan Mutu Terpadu Pesantren dan Madrasah Diniyah, (Jakarta: Diva Pustaka, 2008), hal. 1 
sering disebut kitabgundul. Merupakan satu-satunya metode yang secara formal diajarkan dalam komunitas pesantren di Indonesia. ${ }^{15}$ Dalam pesantren, penggalian hasanah budaya Islam melalui kitab-kitab klasik merupakan salah satu unsur penting dalam keberadaannnya dan yang membedakannya dengan lembaga pendidikan lain.

Pesantren berperan sebagai pusat transmisi dan desiminasi ilmuilmu keislaman, terutama yang besifat kajian-kajian klasik. Maka pengajaran 'kitab kuning telah menjadi karakteristik yang merupakan ciri khas dari proses belajar mengajar di pesantren.

\section{Pengembangan Pendidikan}

Kawasan pengembangan mencakup banyak variasi teknologi yang digunakan dalam pembelajaran. ${ }^{16}$ Pendidikan moral, akidah, dan akhlak harus didukung oleh kemauan, kerjasama yang kompak dan usaha yang sungguh-sungguh dari keluarga/rumah tangga, sekolah dan masyarakat. ${ }^{17}$

Pendidikan Agama Islam adalah usaha sadar untuk menyiapkan siswa dalam meyakini, memahami, menghayati dan mengamalkan agama Islam melalui kegiatan bimbingan, pengarahan atau. latihan dengan

${ }^{15}$ Ibid., hal. 38.

16 Deni Darmawan, Inovasi Pendidikan: Pendekatan Praktik Teknologi Multimedia dan PembelajaranOnline, (Bandung: Remaja Rosdakarya, 2012), hal. 12.

17 Merle J. Schwartz, Effective Character Education, (Newyork: McGraw-Hill, 2008), hal. 7. memperhatikan tuntutan untuk menghormati agama lain dalam hubungan kerukunan antar umat beragama dalam masyarakat untuk mewujudkan kesatuan nasional. ${ }^{18}$

Tujuan pendidikan Islam itu adalah untuk membentuk manusia yang bertanggung jawab terhadap dirinya dan masyarakat guna tercapainya kebahagiaan dunia dan akhirat. Dengan demikian, tujuan akhir dari pendidikan agama Islam itu karena semata-mata untuk beribadah kepada Allah SWT. Dengan cara berusaha melaksanakan semua perintah-Nya dan meningglkan larangan-Nya. ${ }^{19}$

Permasalahan seputar pengembangan model pendidikan pondok pesantren dalam hubungannya dengan peningkatan kualitas sumberdaya manusia merupakan isu aktual dalam arus perbincangan kepesantrenan kontemporer. Maraknya perbincangan mengenai isu tersebut tidak bisa dilepaskan dari realitas empirik keberadaan pesantren dewasa ini yang dinilai kurang mampu mengoptimalisasi potensi yang dimilikinya. Setidaknya terdapat dua potensi besar yang dimiliki pesantren yaitu potensi pendidikan dan pengembangan masyarakat.

\section{Indikator Pengembangan Pendidikan \\ Indikator adalah tujuan} pembelajaran yang diperoleh dari hasil analisis tujuan. Perumusan indikator

\footnotetext{
18 Akmal Hawi, Kompetensi Guru Pendidikan Agama Islam, (Jakarta: Raja Grafindo Persada, 2014), hal. 19.

${ }^{19}$ Ibid., hal. 21.
} 
didasarkan pada sintesis pembelajaran dan identifikasi tingkah laku. ${ }^{20}$ Indikator merupakan parameter/ukuran (alat ukur), karakter, ciri-ciri atau tanda-tanda, ia dilahirkan dari teori yang telah dibangun dari tema atau variabel, dan indikator juga sebagai sumber utama dalam membuat atau pengembangan instrument, artinya tidak ada instrument tanpa indikator.

Pengembangan adalah suatu proses mendapatkan pengalaman, keahlian dan sikap untuk menjadi sesuatu atau meraih sukses sebagai pemimpin dalam suatu organisasi. Oleh karena itu, kegiatan pengembangan ditujukan untuk membantu seseorang untuk dapat menangani persoalannya di masa mendatang. Kegiatan pendidikan dan pengembangan memberikan manfaat kepada lembaga, berupa keahlian, keterampilan yang akan menjadi aset yang berharga bagi lembaga.

Dewasa ini, efisiensi
merupakan suatu ukuran dalam
membandingkan penggunaan masukan (input) yang direncanakan dengan penggunaan masukan yang sebenarnya terlaksana. Jika masukan yang sebenarnya digunakan semakin besar penghematannya, maka tingkat efisiensi semakin tinggi, tetapi semakin kecil masukan yang dapat dihemat, semakin rendah tingkat efisiensi. Pengertian efisiensi di sini lebih berorientasi kepada masukan

20 Trianto, Model Pembelajaran Terpadu: Konsep, Strategi, dan Implementasinya dalam Kurikulum Tingkat Satuan Pendidikan (KTSP), (Jakarta: Bumi Aksara, 2011), hal. 85. sedangkan masalah keluaran (output) kurang menjadi perhatian. Efektivitas merupakan suatu ukuran yang memberikan gambaran seberapa jauh target dapat dicapai. Pengertian efektivitas ini lebih berorientasi kepada keluaran sedangkan penggunaan masukan kurang menjadi perhatian utama. $^{21}$

Efektivitas dan efisiensi erat kaitannya dengan kualitas, sebagai suatu ukuran yang menyatakan seberapa jauh telah dipenuhi berbagai persyaratan, spesifikasi dan harapan. Efektivitas adalah ukuran keberhasilan tujuan organisasi. Efektivitas dapat juga ditela'ah dari: (1) masukan yang merata; (2) keluaran yang banyak dan bermutu tinggi; (3) ilmu dan keluaran yang relevan dengan kebutuhan masyarakat yang sedang membangun; (4) pendapatan tamatan yang memadai. $^{22}$

Suparno Eko Widodo, pengembangan (development) adalah proses peningkatan keterampilan teknis, teoritik, konseptual dan moral karyawan melalui pendidikan dan pelatihan, fungsi pengembangan meliputi: penilaian prestasi kerja, perencanaan karir, pendidikan dan pelatihan, pemberian tugas, mutasi dan promosi, motivasi dan disiplin kerja.

\footnotetext{
21 E. Mulyasa, Menjadi Kepala Sekolah Profesional, (Bandung: PT Remaja Rosdakarya, 2009), hal. 132.

22 Anonim, Tim Dosen Administrasi Pendidikan Universitas Pendidikan Insonesia, Manajemen Pendidikan, (Bandung: Alfabeta, 2008), hal. 89.
} 


\section{KESIMPULAN}

Pondok pesantren sebagai agen pengembangan masyarakat, sangat diharapkan menyiapkan sejumlah konsep pengembangan sumber daya manusia, baik untuk peningkatan kualitas pondok pesantren maupun peningkatan kualitas kehidupan masyarakat. Berbicara masalah sumber daya manusia, sebenarnya terdiri dari dua aspek, yakni kuantitas dan kualitas. Kuantitas menyangkut jumlah sumber daya manusia (penduduk) yang kurang penting kontribusinya dalam pembangunan, dibandingkan dengan aspek kualitas. Bahkan kuantitas sumber daya manusia tanpa disertai kualitas yang baik akan menjadi beban pembangunan suatu bangsa.

Pengembangan

sistem

pendidikan di pesantren hendaknya dilakukan secara terpadu, tidak hanya melihat pada satu sisi tetapi melihat seluruh komponen pesantren sebagai satu kesatuan yang utuh yang saling berkaitan. Pemikiran dan operasionalisasi menejemen pendidikan terpadu akan banyak ditentukan oleh tujuan dan arah keterpaduan, yang menyatakan bahwa arah pendidikan di pondok pesantren saat ini adalah dalam pembinaan IMTAQ, IPTEK dan Skill fungsional atas dasar kebutuhan. Keterpaduan akan ditekankan saat ini harus dimiliki oleh lembaga pendidikan pesantren dengan strategi pengembangan pendidikan yang telah dirumuskan.

Atas dasar beberapa pemikiran di atas, pembahasan di sini berfokus pada masalah Implementasi dari stategi pendidikan pesantren. Implementasi merupakan suatu proses penerapan ide, konsep, kebijakan, atau inovasi dalam suatu tindakan praktis sehingga memberikan dampak, berupa perubahan pengetahuan, ketrampilan, nilai, dan sikap. Dalam upaya pengembangan pendidikan di pondok pesantren. tidak bisa terlepas dari sikap dan tindakan kyai pimpinan pondok. Hal ini dapat dilihat bahwa hampir semua upaya peningkatan kualitas santri selalu datang dari kyai. Meski ide tersebut bisa berasal dari para ustadz/ah atau para pengasuh. Tetapi sebagian besar kreatifitas yang muncul adalah hasil inisiatif dari kyai. Sehingga dalam hal kreatifitas pikiran atau ide didominasi oleh kyai.

\section{DAFTAR PUSTAKA}

A Azra, D Afrianti, The Journal of Islamic Boarding School Pesantren and Madrasah: Muslim School and National Ideals in Indonesia, RW Hefiner and Politics of Modern Muslim, 2008.

Akmal Hawi, Kompetensi Guru Pendidikan Agama Islam, (Jakarta: Raja Grafindo Persada, 2014).

Amin Haedari, Peningkatan Mutu Terpadu Pesantren dan Madrasah Diniyah, (Jakarta: Diva Pustaka, 2008).

Anonim, Tim Dosen Administrasi Pendidikan Universitas Pendidikan Insonesia, 
Manajemen

Pendidikan,

(Bandung: Alfabeta, 2008).

Badarus Syamsi, Akulturasi Pesantren

Jawa di Jambi, Kontektualita,

Vol. 28, No. 1, (Institut

Agama Islam Negeri (IAIN)

Sulthan Thaha Saifuddin

Jambi, 2013).

Deni Darmawan, Inovasi Pendidikan:

Pendekatan Praktik Teknologi

Multimedia dan

PembelajaranOnline,

(Bandung:

Remaja

Rosdakarya, 2012).

Diding

Nurdin,Pengelolaan

Pendidikan dari Teori Menuju

Implementasi, (Jakarta: Raja

Grafindo Persada, 2015).

E. Mulyasa, Menjadi Kepala Sekolah

Profesional, (Bandung: PT

Remaja Rosdakarya, 2009).

Haedari, Amin dan Ishom El-

Saha, Peningkatan Mutu

Terpadu Pesantren dan

Madrasah Diniyah. (Jakarta:

Diva Pustaka, 2008).

Kasful Anwar, Kepemimpinan Pondok

Pesantren, Disertasi: UPI.

Merle J. Schwartz, Effective Character

Education,

(Newyork:

McGraw-Hill, 2008).

Mujamil Qomar, Manajemen

Pendidikan Islam, (Malang:

Erlangga, 2008).

Mujamil Qomar, Manajemen Lembaga

Pendidikan Islam, (Jakarta:

Erlangga, 2007).
Ramayulis, Ilmu Pendidikan Islam, (Jakarta: Kalam Mulia, 2007).

Soekidjo

Notoatamodjo, Pengembangan Sumber Daya Manusia, (Jakarta: PT. Rineka Cipta, 2008).

Trianto, Model Pembelajaran Terpadu:

Konsep, Strategi, dan Implementasinya dalam

Kurikulum Tingkat Satuan

Pendidikan (KTSP), (Jakarta:

Bumi Aksara, 2011).

Udin Syaefudin Sa'ud dan Abin

Syamsuddin, Perencanaan

Pendidikan Suatu Pendekatan

Komprehensif, (Bandung: $\mathrm{Pt}$

Remaja Rosdakarya, 2008).

Veithzal Rivai, dkk, Education Management Ed. 1, (Jakarta: Rajawali, 2010).

Zainuddin Ali, Pendidikan Agama Islam, (Jakarta: Bumi Aksara, 2012). 